This is a revised personal version of the text of the final journal article, which is made available for scholarly purposes only, in accordance with the journal's author permissions. The full citation is:

Zhang Y., Banks C. J., Heaven S. (2012) Co-digestion of source segregated domestic food waste to improve process stability. Bioresource Technology 114, 168-178. doi: 10.1016/j.biortech.2012.03.040

\title{
Co-digestion of source segregated domestic food waste to improve process stability
}

\section{Author names and affiliations}

Yue Zhang ${ }^{1}$, Charles J. Banks, Sonia Heaven

Faculty of Engineering and the Environment, University of Southampton, Southampton SO17 1BJ, UK

\begin{abstract}
Cattle slurry and card packaging were used to improve the operational stability of food waste digestion, with the aim of reducing digestate total ammoniacal nitrogen concentrations compared to food waste only. Use of cattle slurry could have major environmental benefits through reducing greenhouse gas emissions associated with current management practices; whilst card packaging is closely linked to food waste and could be co-collected as a source segregated material. Both options increase the renewable energy potential whilst retaining organic matter and nutrients for soil replenishment. Co-digestion allowed higher organic loadings and gave a more stable process. A high ammonia inoculum acclimated more readily to cattle slurry than card
\end{abstract}

\footnotetext{
1 * Corresponding author: Tel.: +44 (0)2380 598363; fax: +44 (0)2380 677519; E-mail address: Y.Zhang@soton.ac.uk (Yue Zhang)
} 
packaging, probably through supplementation by trace elements and micro-organisms. Long-term operation at a 75-litre scale showed a characteristic pattern of volatile fatty acid accumulation in mono-digestion of food waste, and allowed performance parameters to be determined for the co-digestion substrates.

Keywords: Food waste; card packaging; cattle slurry; ammonia; specific methane production

\section{Introduction}

Anaerobic digestion of organic material in municipal solid waste provides renewable energy in the form of biogas (Mata Alvarez, 2003) and can also offer a means of recycling valuable plant nutrients back to agricultural land (Lukehurst et al., 2010). To achieve the latter requires source segregation of targeted organics, as the material arising from mechanical pre-treatment has a high level of contamination, with heavy metal concentrations exceeding the accepted values for agricultural land used in food production (BioAbV, 1998; PAS 110, 2010). Food waste from both domestic and commercial sources has been targeted for biogas production because of its high biochemical methane potential (Zhang et al., 2011; Banks and Zhang, 2010), whilst its high water content makes energy recovery through thermal treatment unattractive (Ahring, 2003). It can, however, be difficult to digest as a mono-substrate (Zhang et al., 2011), leading to digester instability and in some cases failure (Neiva Correia et al., 2008; Resch, 2011; Palatsi, 2011). Recent work by Banks et al. (2012) has shown that stable digestion is possible at the high ammonia concentrations associated with food waste by selective trace element addition. An alternative approach is to co-digest food 
waste with other waste materials so as to increase the carbon to nitrogen ratio as a means of overcoming process limitations due to ammonia inhibition (Zhang et al., 2011). There are also strong environmental reasons for adopting co-digestion: treating animal manures in a controlled process reduces the fugitive emissions associated with manure management and could lead to greenhouse gas savings (Clemens, 2006; Banks et al., 2007; Marañón et al., 2011). The mixing of a high energy potential substrate such as food waste with low energy potential animal slurries can make the overall process economic (Angelidaki and Ellegaard, 2003;El-Mashad and Zhang, 2010; Zhang et al., 2011). A number of studies have explored this option and shown improved performance or increased process stability (Callaghan et al., 2002; Hartmann and Ahring, 2005; Capela et al., 2007; Alvarez and Lidén, 2008). The concept has also been successfully applied to achieve better nutrient management by cooperative schemes in Denmark (Holm-Nielsen et al., 2009), mainly using commercial or industrial sources of biodegradable wastes from animal slaughter and food processing (Raven and Gregersen, 2007). These schemes are often regarded as a model of best practice (Braun and Wellinger, 2003); not all of the Danish co-digestion plants have worked without problems, however, probably due to unwise selection of co-substrates (Nielsen and Angelidaki, 2008).

Banks et al. (2011a) suggested that on-farm co-digestion of source segregated domestic food waste was the most effective means of making cattle slurry digestion economically viable, with associated benefits in greenhouse gas reduction and nutrient management. In dense urban areas where centralised digestion may be more appropriate, card packaging material becomes an attractive co-substrate as it is generated and can be co- 
collected in close association with food waste, and is generally available in tonnage quantities as a low or negative value stream from materials recovery facilities. The aim of the current work was to investigate the co-digestion of source segregated domestic food waste with cattle slurry and also with card packaging: in both cases it was anticipated that the carbon/nitrogen $(\mathrm{C} / \mathrm{N})$ ratio would be reduced, allowing operation at higher loading rates with enhanced process stability.

\section{Methods}

\subsection{Materials}

\subsubsection{Digesters}

The work was carried out in laboratory and pilot-scale mechanically mixed mesophilic digesters which were fed daily. The laboratory-scale digesters each had a 4-litre working volume and were constructed of PVC tube with gas-tight top and bottom plates. The top plate was fitted with a gas outlet, a feed port sealed with a rubber bung, and a draught tube liquid seal through which a stainless steel asymmetric bar stirrer was inserted with a 40 rpm motor mounted directly on the top plate. Temperature was maintained at $36 \pm 1{ }^{\circ} \mathrm{C}$ by circulating water from a thermostatically-controlled bath through a heating coil around the digesters. Semi-continuous operation was achieved by daily removal of digestate through an outlet port in the base of each digester, followed by substrate addition via the feed port. The pilot-scale digesters were of the same design as the laboratory-scale digesters except that their working volume was 751 and the temperature was maintained at $36 \pm 1{ }^{\circ} \mathrm{C}$ by an internal heat exchanger. In both cases biogas production was 
measured using tipping-bucket gas counters with continuous data logging (Walker et al., 2009).

\subsubsection{Food waste}

Source segregated domestic food waste (FW) delivered to the South Shropshire digestion facility at Ludlow, UK was used in the study (Banks et al., 2011b). The material was first taken out of biodegradable plastic bags and any non-biodegradable contaminants were removed. It was then homogenised using a macerating grinder (S52/010 Waste Disposer, IMC Limited, UK), packed into 4-litre plastic storage containers, and frozen at $-18{ }^{\circ} \mathrm{C}$. Before use the feedstock was thawed, and stored at $4{ }^{\circ} \mathrm{C}$ for no more than one week. The characteristics of the FW are given in Table 1.

\subsubsection{Cattle slurry}

Three batches of cattle slurry (CS) was obtained from Parker's Farm, Hampshire, UK, over the period of experiment. It was then homogenised and stored in the same way as for food waste. Table 1 shows the typical characteristics of the material.

\subsubsection{Card packaging}

One hundred kilograms of mixed card packaging (CP) was collected from the reject stream of the Alton Materials Recovery Facility (MRF) run by Veolia Environmental Services, Hampshire, UK. This material was sorted into three fractions and shredded into $50 \times 5 \mathrm{~mm}$ pieces using office shredders, and then blended again in defined proportions consisting of $29.6 \%$ of corrugated cardboard, $62.5 \%$ of card packaging and $7.9 \%$ of other card on a fresh weight basis. The proportions were calculated based on 
these different recyclable carton types in the UK household waste stream. Table 1 gives the characteristics of the material.

\subsubsection{Inoculum}

The inoculum for the 4-litre laboratory-scale trial was taken from a 35-litre food waste digester that had been acclimated to this substrate over a period of 284 days at an organic loading rate (OLR) of $2 \mathrm{~kg}$ volatile solids (VS) $\mathrm{m}^{-3}$ day $^{-1}$ (Banks and Zhang, 2010). Before use the digestate was sieved through a $1 \mathrm{~mm}$ mesh to remove any large particles. The 75-litre digesters were inoculated with digestate from a mesophilic digester treating municipal wastewater biosolids at Millbrook Wastewater Treatment Plant (WWTP), Southampton, UK.

\subsection{Digester operation and monitoring}

Two laboratory-scale digesters were fed with a mixture of FW and CS, at an initial ratio of $20: 80 \%$ on a VS basis. Two more digesters were fed with FW and CP in the proportion of 78.4:21.6 on a fresh weight basis which was calculated based on their relative quantities in the $\mathrm{UK}$ household waste stream, giving a $\mathrm{FW}: \mathrm{CP}$ ratio of 53:47 on a VS basis. To ensure homogeneity the card packaging was prepared by wet maceration, which reduced the total solids content from $94 \%$ to around $20 \%$. A fifth digester was fed only on FW and acted as a control. The total OLR for all digesters was $2 \mathrm{~kg} \mathrm{VS} \mathrm{m}^{-3}$ day $^{-1}$ at the start of the trial. The solids and liquid retention times were uncoupled and a nominal solids retention time (SRT) of 30 days was maintained by sieving digestate through a $1 \mathrm{~mm}$ mesh, after which the appropriate quantity of solids was discarded and the amount of liquid required to maintain the digester at a constant volume was returned 
to the digester with the fresh substrate. The operating regime changed as the experiment progressed, and details are given in Table 2. The trial ran for 329 days during which time the loading was successively increased, and the proportion of $\mathrm{FW}$ : CS was also raised to a final value of 60:40 on a VS basis to cover a range of operating conditions with different proportions of the co-substrates.

The OLR in the 75-litre digesters was $2 \mathrm{~kg} \mathrm{VS} \mathrm{m}^{-3} \mathrm{day}^{-1}$ and a nominal SRT of 30 days was maintained through liquor re-circulation. One digester was fed on FW only, one on a FW:CS mix at a 20:80 ratio on a VS basis, corresponding to the initial mixture in the laboratory-scale trials; and one on a FW:CP mix at a 53:47 VS ratio. This ratio was the same as used in the laboratory-scale trial, but in this trial the card packaging was not wet macerated. The digesters were operated for 308 days, or more than 10 solids retention times.

All digesters were monitored daily for biogas production and $\mathrm{pH}$. Other digestate parameters such as solids, volatile fatty acids (VFA), total ammoniacal nitrogen (TAN), alkalinity, and biogas composition were analysed a minimum of once per week and often more frequently. All gas volumes reported are corrected to standard temperature and pressure (STP) of $0{ }^{\circ} \mathrm{C}, 101.325 \mathrm{kPa}$.

\subsection{Digestate biostability}

Digestate stability assays were carried out in 1.4-litre working capacity continuously stirred tank reactor (CSTR) digesters at $36 \pm 1{ }^{\circ} \mathrm{C}$. The biogas produced was collected using gas impermeable sampling bags (SKC Ltd., UK), with biogas volumes measured 
according to the weight gasometer method (Walker et al., 2009). Inoculum was taken from the Millbrook WWTP digester and sieved through a $1 \mathrm{~mm}$ mesh before use.

Whole digestate and digestate fibre were tested at an inoculum-to-substrate $(i / s)$ ratio of 2 on a VS basis. In the case of digestate liquors, no inoculum was added and the residual gas production occurred as a result of the microbial consortium already present. The test was set up immediately after digestate had been drained from the digester and the liquor separated from the fibre, and ran for 100 days. The test materials were run in duplicate, with duplicate inoculum-only blanks and positive controls.

\subsection{Analytical methods}

Total solids (TS) and volatile solids (VS) were measured using Standard Method 2540 G (APHA, 2005). pH was determined using a Jenway 3010 meter (Bibby Scientific Ltd., UK) with a combination glass electrode, calibrated in buffers at pH 4.0, 7.0 and 9.2 (Fisher Scientific, UK). Alkalinity was measured by titration with $0.25 \mathrm{~N} \mathrm{H}_{2} \mathrm{SO}_{4}$ to endpoints of pH 5.75 and 4.3, allowing calculation of total (TA), partial (PA) and intermediate alkalinity (IA) (Ripley et al., 1986). Total Kjeldahl nitrogen (TKN) was determined using a Kjeltech block digester and TAN by steam distillation unit according to the manufacturer's instructions (Foss Ltd., Warrington, UK). Volatile fatty acids were quantified in a Shimazdu GC-2010 gas chromatograph (Shimadzu, Milton Keynes, UK), using a flame ionisation detector and a capillary column type SGE BP-21. Biogas composition $\left(\mathrm{CH}_{4}\right.$ and $\left.\mathrm{CO}_{2}\right)$ was determined using a Varian star $3400 \mathrm{CX}$ gas chromatograph, calibrated with $65 \%$ (v/v) $\mathrm{CH}_{4}$ and $35 \%$ (v/v) $\mathrm{CO}_{2}$. Trace element concentrations were determined using ICP-MS or ICP-OES at a commercial laboratory 
Severn Trent Services (Coventry, UK) after in-house hydrochloric-nitric acid digestion (SCA, 1986).

\section{$3 \quad$ Results and discussion}

\subsection{4-litre digester trial}

The inoculum used in this trial was deliberately drawn from a digester previously fed on the same type of food waste at a low OLR over a long period. The aim was to show that continued feeding of this well-established but already stressed inoculum would lead to further deterioration, and to allow comparison of the effect of co-substrate addition.

\subsubsection{Food waste only}

The inoculum used had an initial total VFA concentration above $7000 \mathrm{mg} \mathrm{l}^{-1}$, TAN close to $3500 \mathrm{mg} \mathrm{l}^{-1}$ and free ammonia around $270 \mathrm{mg} \mathrm{l}^{-1}$. Within one SRT, the specific methane production (SMP) of the digester fed with FW as a single substrate fell to less than $10 \%$ of its starting value. The $\mathrm{pH}$ had dropped below 6.0 , the biogas contained less than $10 \%$ methane and a high hydrogen peak was seen in GC analysis. These results indicated that the digestion had failed and feeding was stopped, but the biogas production, biogas composition and digestate parameters were still monitored.

\subsubsection{Food waste and cattle slurry}

In the two digesters fed with the FW:CS mix, stable biogas production was achieved within about 0.5 SRT. Measured over the period day 30-98 the specific methane production was $0.218 \mathrm{STP} \mathrm{m}^{3} \mathrm{CH}_{4} \mathrm{~kg}^{-1} \mathrm{VS}_{\text {added }}$ (Fig. 1a); as expected, this was lower than the value obtained for digestion of FW only at the beginning of the trial. The 
biogas methane content (Fig. 1b) increased and reached a value of $62.7 \%$. There was also a decrease in the VFA concentration in the digesters (Fig. 1c and d), which may have been due in part to methane production, and in part to hydraulic flushing of VFA out of the system. The propionic acid (HPr) concentration decreased rapidly, coupled with a rise in acetic acid (HAc). At the end of the first SRT HPr formed only $3.8 \%$ of total VFA with HAc being the predominant species at 92\%. After 1.5 SRT (day 45) HAc was the only VFA species present in the digestate, and after 2 SRT (day 60) the total VFA concentration had dropped to less than $200 \mathrm{mg}^{-1}$. These results indicated that the addition of CS had stabilised the digestion and had also brought about a reduction in total ammoniacal nitrogen (Fig. 1e) and a stable $\mathrm{pH}$ between 7.5 and 8.0 (Fig. 1f).

The digesters running on a FW:CS mix were considered to have reached steady state after 3 SRT, and on day 99 the proportion of FW in the mixture was increased to $40 \%$ on a VS basis to improve the specific and volumetric methane production (Fig. 1a). The digesters adapted to this change without VFA accumulation (Fig. 1c and d), and ran stably for a further period of 2.5 SRT. From Fig. 1a it can be seen that the specific methane production increased by about $10 \%$ and the volumetric methane production increased from 0.43 to $0.48 \mathrm{STP} \mathrm{m}^{3} \mathrm{CH}_{4} \mathrm{~m}^{-3}$ day $^{-1}$.

At the end of the sixth SRT (day 176) the OLR was increased to $3 \mathrm{~kg} \mathrm{VS} \mathrm{m}^{-3}$ day $^{-1}$ with the proportion of $\mathrm{FW}: \mathrm{CS}$ remaining at 40:60. In one of the digesters this caused a rapid increase in VFA concentration followed by a fall (Fig. 1c), coupled with a fluctuating methane content and yield (Fig. 1a and b). Unstable biogas and methane production was 
also observed in the other digester, although VFA concentrations remained below 200 $\mathrm{mg}^{-1}$ (Fig. 1d); it may be that a VFA spike in this digester was not seen, if it disappeared rapidly between sampling times. In Fig. 1a it can be seen that after the OLR rose to $3 \mathrm{~kg} \mathrm{VS} \mathrm{m}^{-3} \mathrm{day}^{-1}$ the volumetric methane production increased by $38 \%$ to reach $0.66 \mathrm{STP} \mathrm{m}^{3} \mathrm{CH}_{4} \mathrm{~m}^{-3}$ day $^{-1}$, but the specific methane production declined to $92 \%$ of that obtained at an OLR of $2 \mathrm{~kg} \mathrm{VS} \mathrm{m}^{-3} \mathrm{day}^{-1}$. The probable reason for this is because the cattle slurry had a relatively low solids content (only around 7\% of VS in fresh matter), and therefore the nominal liquid retention time was reduced to around 35 days, causing a higher proportion of undegraded material to be flushed out of the digesters.

On day 232, after the digesters had run at an OLR of $3 \mathrm{~kg} \mathrm{VS} \mathrm{m}^{-3}$ day $^{-1}$ for $2 \mathrm{SRT}$, the proportion of food waste in the mixture was increased from $40 \%$ to $60 \%$. This reduced the volume of feedstock needed to achieve the required OLR, mitigating the wash-out effect caused by the low solids content of cattle slurry. In this way it was possible to obtain a further increase in OLR without reducing the solid and liquid retention times to less than 30 days. The digesters adapted smoothly to the change in feedstock proportions, and the volumetric methane production increased by $34 \%$ compared to that for a 40:60 FW:CS mix (Fig. 1a). All stability parameters remained in a safe range with VFA concentrations $<150 \mathrm{mg} \mathrm{l}^{-1}$, TAN $1600 \mathrm{mg} \mathrm{l}^{-1}$, and a $\mathrm{pH}$ of 7.5 .

To further improve the volumetric productivity, at the end of the tenth SRT (day 295) the OLR was increased to $4 \mathrm{~kg} \mathrm{VS} \mathrm{m}^{-3}$ day $^{-1}$, with the proportion of food waste to cattle slurry remaining at 60:40 on a VS basis. At the end of the trial the digesters had been running under this regime for more than one SRT without any fluctuation in stability 
parameters. This is longer than necessary for any loading shock to become apparent, and it was therefore considered that the operation of the digesters corresponded to steady state conditions with a specific methane production of $0.306 \mathrm{STP} \mathrm{m} \mathrm{CH}_{4} \mathrm{~kg}^{-1}$ VS added and a volumetric production of 1.23 $\mathrm{STP} \mathrm{m}^{3} \mathrm{CH}_{4} \mathrm{~m}^{-3}$ day $^{-1}$ (Fig. 1a).

\subsubsection{Food waste and card packaging}

Over the first 100 days of operation the specific methane production (Fig. 2a) showed an initial decline to a value between 0.26 and $0.28 \mathrm{STP} \mathrm{m}^{3} \mathrm{CH}_{4} \mathrm{~kg}^{-1} \mathrm{VS}_{\text {added }}$ followed by a peak and then a return to a value around $0.30 \mathrm{STP} \mathrm{m}^{3} \mathrm{CH}_{4} \mathrm{~kg}^{-1} \mathrm{VS}_{\text {added }}$. The biogas methane content (Fig. 2b) showed some variability over this period in the range $50-60 \%$, with an average around 54\%. The VFA profile in the two digesters (Fig. 2c and d) showed a very similar pattern, with the HPr concentration decreasing rapidly after about 1 SRT coupled with increasing concentrations of HAc and, to a lesser extent, of iso-valeric acid. The HAc was then consumed with a decrease from $5400 \mathrm{mg} \mathrm{l}^{-1}$ at day 35 to $1100 \mathrm{mg}^{-1}$ at day 50, at which time HPr was less than $50 \mathrm{mg}^{-1}$ (Fig. 2c and d). This pattern explains the changes in specific methane yield and biogas methane concentration noted above. A further rise in HAc concentration was observed at the end of the second SRT (day 50-60). Due to the low TKN content of card packaging, the TAN fell sharply from an initial concentration of $3400 \mathrm{mg}^{-1}$ to $1800 \mathrm{mg}^{-1}$ by the end of the second SRT, and this may have contributed to some extent to the recovery process. During this period the free ammonia concentration dropped to less than $100 \mathrm{mg}$ $1^{-1}$ (Fig. 2e) accompanied by a gradual fall in $\mathrm{pH}$ as the alkalinity dropped to $<10,000$ $\mathrm{mg} \mathrm{CaCO}_{3} \mathrm{l}^{-1}$ (Fig. 2f). The HAc concentration was stable at around $1500 \mathrm{mg} \mathrm{l}^{-1}$ during the third SRT, although TAN continued to fall. 
The OLR was increased from 2 to $3 \mathrm{~kg} \mathrm{VS} \mathrm{m}^{-3}$ day $^{-1}$ at the beginning of the fourth SRT time (day 99) which resulted in the volumetric methane production increasing from 0.60 to $0.69 \mathrm{~m}^{3} \mathrm{CH}_{4} \mathrm{~m}^{-3}$ day $^{-1}$ over the following 2 weeks (Fig. 2a). The VFA concentrations were seen to increase shortly afterwards (Fig. 2c and d). With the continuing fall in TAN (Fig. 2e) and alkalinity (Fig. 2f), the reduced buffering capacity was insufficient to prevent a rapid decline in $\mathrm{pH}$ to a critical point (Fig. 2f). A hydrogen peak was also noted in the GC analysis of biogas composition when the methane content dropped to $25 \%$ and the digesters were failing. The VFA profile showed that the condition of one digester (Fig. 2c) was worse than the other (Fig. 2d). In an attempt to stabilise the $\mathrm{pH}$ and recover the most badly affected digester $(\mathrm{FW}+\mathrm{CP}$ digester No. 1$)$ it was fed from day 134 with cattle slurry as the only substrate for 42 days, with the aim of providing additional buffering and nutrients essential for anaerobic digestion and as a source of methanogenic micro-organisms. The second digester of the pair (FW + CP digester No. 2) was left without feeding for the same length of time. Both digesters showed signs of recovery. The VFA concentration in the digester fed with cattle slurry dropped from its peak value of $11,000 \mathrm{mg} \mathrm{l}^{-1}$ to a level of $1200 \mathrm{mg} \mathrm{l}^{-1}$ (Fig. 2c), the biogas methane percentage reached $60 \%$ (Fig. 2b), and the pH rose to 7.3 (Fig. 2f). In the other digester the $\mathrm{pH}$ climbed to around 7.5 (Fig. 2f), VFA were almost completely consumed (Fig. 2d), and TAN rose (Fig. 2e) as degradation of the remaining organic materials in the digestate increased the buffering capacity. After recovery both digesters were again fed with the mixture of food waste and card packaging at an OLR of $2 \mathrm{~kg}$ $\mathrm{VS} \mathrm{m}^{-3}$ day $^{-1}$ from day 176 . The cattle slurry recovered digester showed good operational stability within 2 weeks with the total VFA concentration falling then 
remaining below $100 \mathrm{mg} \mathrm{l}^{-1}$ (Fig. 2c). The digester without cattle slurry addition showed a fall in $\mathrm{pH}$ to less than 7.0 (Fig. 2f) and an increase in the VFA concentration to $3000 \mathrm{mg} \mathrm{l}^{-1}$ (Fig. 2d), and it was necessary intermittently to stop feed addition over the following two weekends to maintain operational stability. Continuous feeding was then resumed, after which the digester operated stably for around 2 SRT and showed a similar performance to the cattle slurry recovered digester. It is interesting to note that the persistent HAc concentration of around $1500 \mathrm{mg}^{-1}$ observed during the first part of the run at an OLR of $2 \mathrm{~kg} \mathrm{VS} \mathrm{m}^{-3}$ day $^{-1}$ was undetectable after the re-acclimation at the start of the second part (Fig. 2c and d).

An explanation for the observed behaviour is as follows: The digesters were started using an inoculum of digestate from a food waste digester which was operating at a TAN concentration of around $3400 \mathrm{mg} \mathrm{l}^{-1}$ and was likely to have some inhibition of acetoclastic methanogenesis (Karakashev et al., 2006; Schnurer and Nordberg, 2008). Although, the addition of card packaging lowered the TAN concentration it was evident from the existence of an acetic acid plateau (Fig. 2c and d) that the population of acetoclastic methanogens or the acetate oxidisation pathway was not entirely restored within the first three SRT. The increase in OLR from 2 to $3 \mathrm{~kg} \mathrm{VS} \mathrm{m}^{-3} \mathrm{day}^{-1}$ increased the load on hydrogenotrophic and/or acetoclastic pathways, and when the methane production route was unable to consume all the hydrogen produced, product-induced feedback inhibition would have caused VFA build-up. With the TAN concentration reducing to less than $1000 \mathrm{mg}^{-1}$ there was insufficient buffering capacity to prevent the $\mathrm{pH}$ falling to a level at which the hydrogenotrophic methanogens were affected, bringing the situation to a critical point. The recovery stage allowed the recovery of 
methanogenesis in the digesters and developed a more balanced anaerobic microbial consortium with conditions ideal for both acetoclastic and hydrogenotrophic methanogenesis.

On day 232 the OLR in both digesters was again increased, to $3 \mathrm{~kg} \mathrm{VS} \mathrm{m}^{-3} \mathrm{day}^{-1}$. On this attempt the VFA concentrations and all other operational parameters remained stable (Figure $2 b-f)$. The specific methane production remained the same at 0.315 STP $\mathrm{m}^{3} \mathrm{CH}_{4} \mathrm{~kg}^{-1} \mathrm{VS}$ added and the volumetric production increased by $50 \%$ (Fig. 2a). The OLR was increased to $4 \mathrm{~kg} \mathrm{VS} \mathrm{m}^{-3}$ day $^{-1}$ at the end of the tenth SRT (day 295). By the end of the trial the digesters had been running at this loading for more than one SRT without any fluctuation in stability parameters, and had apparently reached a steady state condition, with a specific methane production of $0.307 \mathrm{STP} \mathrm{m}^{3} \mathrm{~kg}^{-1} \mathrm{VS}$ added and a volumetric methane production of $1.23 \mathrm{STP}^{3} \mathrm{~m}^{-3}$ day ${ }^{-1}$ (Fig. 2a).

\subsection{5-litre digester trial}

As noted above, the 4-litre digesters were initially inoculated with digestate from a food waste digester that was showing signs of incipient instability. This was confirmed by the subsequent failure of the food waste (FW)-only control digester, which continued operating with the same feedstock and OLR. From two SRT onwards it was evident that there were process benefits from adding cattle slurry as co-substrate, as this allowed an increase in OLR from 2 to $4 \mathrm{~kg} \mathrm{VS} \mathrm{m}^{-3}$ day $^{-1}$, with the proportion of food waste in the mix also being increased. The co-digestion of food waste and card packaging failed to stabilise on the first attempt to raise the OLR from 2 to $3 \mathrm{~kg} \mathrm{VS} \mathrm{m}^{-3}$ day $^{-1}$, but the second attempt was successful. This laboratory-scale trial, however, left unanswered 
questions as to why the control digester had failed, and why the addition of cattle slurry or card packaging had recovered an apparently failing inoculum.

To resolve some of these questions, three 75-litre digesters were set up, one of FW-only and one on each of the two mixes, to see if the previous results were reproducible starting with fresh inoculum from a municipal wastewater biosolids digester. The characteristics of this inoculum, including concentrations of macro-nutrients and potentially toxic elements (PTE), are shown in Table 3.

\subsubsection{Co-digestion results}

Experimental results from the 75-litre trial are shown graphically in Fig. 3. It can be seen that methane production did not stabilise until after around 3 SRT (Fig. 3a). Before this, two obvious peaks were observed in each of the digesters. The first appeared towards the end of the first SRT (day 20), and occurred simultaneously in all three digesters; this was followed by a fall in specific methane production, a lower biogas methane content (Fig. 3b), a rapid accumulation of VFA (Fig. 3c), and a drop in pH (Fig. 3e). As this initial production of VFA was consumed, a second biogas production peak appeared. This happened first in the digester running on FW + CS (day 42), second in the digester with FW as the sole substrate (day 49), and last in the one fed with FW + $\mathrm{CP}$ (day 63). The second biogas production peaks also had an associated peak in biogas methane content, as seen in Fig. 3b. After the second biogas peak this parameter stabilised, although there were slight fluctuations later in the digester fed with the FW + CS mix: these may have been due to differences between batches of cattle slurry collected and used. This non-steady behaviour over the first 3 SRT is probably due to 
the need for acclimation of the microbial consortium to the new feedstock and new conditions in the digester. The more robust acid-forming bacteria appear to have adapted to the substrate after the digesters had been running for around half a SRT, and started to consume the accumulated feedstock at an accelerated rate, in the process producing VFA faster than it could be consumed by the acetate oxidising bacteria and methanogens. At this point perhaps the drop in $\mathrm{pH}$ provided optimal conditions for them to consume the VFA, especially acetate; or the moderate OLR of $2 \mathrm{~kg} \mathrm{VS} \mathrm{m}^{-3} \mathrm{day}^{-1}$ simply allowed the more sensitive methanogens to catch up with the acidogens before the $\mathrm{pH}$ dropped to a critical point.

After 3 SRT the co-digestions with cattle slurry and card packaging showed a similar specific methane production to that measured in the 4-litre trial at the same OLR of $2 \mathrm{~kg}$ $\mathrm{VS} \mathrm{m}^{-3}$ day $^{-1}$. All operational parameters were also in the safe range, with TAN less than $2500 \mathrm{mg}^{-1}$ (Fig. 3d) and VFA below $100 \mathrm{mg} \mathrm{l}^{-1}$ (Fig. 3c) throughout the next 7 SRT (210 days) in the trial. Volumetric methane production was 0.43 and 0.64 STP $\mathrm{m}^{3}$ $\mathrm{CH}_{4} \mathrm{~m}^{-3}$ day $^{-1}$ for $\mathrm{FW}+\mathrm{CS}$ and $\mathrm{FW}+\mathrm{CP}$ co-digestion respectively.

The difference in TAN observed between the 4-litre and 75-litre FW + CP co-digestion trials was because the card packaging used in the smaller-scale trial was pre-processed by wet maceration. The addition of water during this pre-treatment reduced the total solids content of the feedstock from $94 \%$ to $20 \%$, thus increasing the rate at which TAN was hydraulically flushed out of the 4-litre digesters.

\subsubsection{Food waste only}


Although the digester fed on FW-only appeared to reach a steady state for biogas production, the TAN concentration exceeded $4000 \mathrm{mg} \mathrm{l}^{-1}$ by day 150 and continued to increase (Fig. 3d). By day 180 there were signs of stress, with an elevated VFA concentration (Fig. 3c) from the previously stable level between day 60 and day 180 of around $200 \mathrm{mg}^{-1}$. Total VFA concentration built up rapidly to above $1000 \mathrm{mg}^{-1}$ by day 210. Initially the VFA was predominantly in the form of HAc but later all species were present, with an initial rise in HPr concentration. The concentration of HPr then fell, accompanied by a further HAc accumulation (Fig. 3f). It can be seen that by the end of the trial VFA concentrations had been fluctuating around 2000-4000 $\mathrm{mg}^{-1}$ for about three retention times. Although VFA concentrations were not as high as some previously seen in digesters fed only on food waste (Banks et al., 2012; Banks et al., 2008), the pattern of accumulation was similar. The $\mathrm{pH}$ in the digester remained high at 8.1 (Fig. 3e) due to sufficient buffering capacity provided by TAN giving an alkalinity over $25,000 \mathrm{mg} \mathrm{l}^{-1}$.

Concentrations of certain key trace elements in both the 4-litre and the 75-litre codigestion trials were analysed part way through the study as parallel work had shown these were critical (Banks et al., 2012): the results are given in Table 4. At the time when the trace element analysis was carried out, the 4-litre digestion trial had run for 161 days or 5.4 SRT, and the 75-litre trial for 140 days (4.7 SRT). Modelled dilute-out profiles for essential trace elements (Fig. 4) suggested that concentrations of cobalt, selenium and tungsten had all dropped to below $1 \mathrm{mg} \mathrm{kg}^{-1} \mathrm{TS}$ in the 75-litre food waste digester by day 210 when the VFA concentration had built up to above $1000 \mathrm{mg} \mathrm{l}^{-1}$. 
This corresponds to the concentration range at which other laboratory-scale food waste co-digestion trials have also failed (Banks et al., 2012).

The results confirmed that the digestion of source segregated domestic food waste by itself led to an increase in VFA, probably as a result of wash-out of essential trace elements combined with an increasing TAN concentration. This condition was prevented by co-digestion with cattle slurry or card packaging, which could contribute essential elements and also reduce the ammonia concentration.

\subsubsection{Digestate characteristics}

The characteristics of the whole digestate, digestate liquor and digestate fibre from the 75-litre digesters are shown in Table 5. The FW-only digestate contained higher concentrations of plant nutrients than digestate from the FW and CS co-digestion trials: this is due not only to the high nitrogen, phosphorus and potassium (NPK) content in food waste, but also because these elements are conserved in the digestion process whilst the food waste input loses a higher proportion of its solids than the mixed feedstock. Concentrations of plant nutrients and PTE in the digestate largely reflected those in the corresponding substrate or mix. All of the samples met the UK standards for PTE (PAS 110, 2010), confirming that co-digestion with CS is unlikely to reduce the high quality of the digestate product obtained from source separated domestic food waste.

Results from the digestate stability tests are shown in Fig. 5. Digestate fibre from the $\mathrm{FW}+\mathrm{CS}$ digester had a relatively high residual methane potential of $0.196 \mathrm{STP} \mathrm{m}^{3} \mathrm{~kg}^{-1}$ 
VS (Fig. 5a); this was because cattle slurry contains a high proportion of lignocellulosic materials which are only slowly degraded and, since the material also has a high water content, it has a relatively short retention time in the digester. Digestate liquor from the $\mathrm{FW}+\mathrm{CS}$ digester had a lower residual methane potential $\left(0.093 \mathrm{STP}^{3} \mathrm{~kg}^{-1} \mathrm{VS}\right.$, Fig. 5b) than the digestate fibre, perhaps due to the lignocellulosic materials in the fibre component. The residual methane potentials from FW + CP digestate fibre (0.110 STP $\mathrm{m}^{3} \mathrm{~kg}^{-1}$ VS, Fig. 5c) and digestate liquor (0.079 STP $\mathrm{m}^{3} \mathrm{~kg}^{-1}$ VS, Fig. 5d) were less than that from FW + CS digestate fibre and liquor. FW-only digestate had the highest residual methane potential of $0.203 \mathrm{STP}^{3} \mathrm{~kg}^{-1} \mathrm{VS}$ (Fig. 5e); this was probably because the larger-scale food waste digester had VFA concentration of $2600 \mathrm{mg} \mathrm{l}^{-1}$ when the digestate sample was taken on day 286. The UK PAS 110 (2010) sets digestate stability limits of VFA $<0.43 \mathrm{~g} \mathrm{COD} \mathrm{g}^{-1} \mathrm{VS}$ and residual biogas potential $<0.25 \mathrm{~g}^{-1} \mathrm{VS}$ in a 28-day test duration. According to these criteria, both fractions of the mixed FW + CS and FW + CP digestate would pass. This requirement may however suggest a reason for not uncoupling the solids and liquids retention time, as the relatively short SRT of 30 days means a higher proportion of the digestate solids will not be broken down. Although the FW-only digestate also passed the UK PAS 110 (2010) digestate stability limits, it would probably fail if the digester was run for a longer period and the expected gradual build-up of VFA continued (Banks et al., 2012, 2011b, 2008).

\section{Conclusions}


Digestion of source-segregated domestic food waste at low OLR showed long-term accumulation of volatile fatty acids, confirming results from earlier work. Co-digestion with cattle slurry and card packaging reduced ammonia concentrations to non-inhibitory levels, and allowed an increase in OLR to $4 \mathrm{~kg} \mathrm{VS} \mathrm{m}^{-3}$ day $^{-1}$ with enhanced volumetric methane productions. Both co-digestates were low in potentially toxic elements and showed low residual methane potential. Trace element analysis suggested food waste may lack cobalt, selenium and tungsten and these may be supplemented by the codigestates. Pilot-scale studies demonstrated long-term process stability of co-digestion with cattle slurry and card packaging compared to mono-digestion of food waste.

\section{Acknowledgements}

The authors wish to thank the UK Government's Department for Environment Food and Rural Affairs (Defra) and the EU 7th Framework programme for supporting this work through Grant Nos. WR1208 and 241334 (VALORGAS), respectively.

\section{References}

1. APHA, 2005. Standard Methods for the Examination of Water and Wastewater, 21st ed. American Public Health Association, American Water Works Association, Water Environment Federation, Washington, USA.

2. Ahring, B.K., 2003. Perspectives for anaerobic digestion. Adv. Biochem. Eng. Biotechnol. 81, 1-30.

3. Alvarez, R., Lidén, G., 2008. Semi-continuous co-digestion of solid slaughterhouse waste, manure, and fruit and vegetable waste. Renew. Energ. 33, 726-734. 
4. Angelidaki, I., Ellegaard, L., 2003. Codigestion of manure and organic wastes in centralized biogas plants. Appl. Biochem. Biotechnol. 109, 95-105.

5. Banks, C.J., Zhang, Y., Jiang, Y., Heaven, S., 2012. Trace element requirements for stable food waste digestion at elevated ammonia concentrations, Bioresour. Technol. $104,127-135$.

6. Banks, C.J., Salter, A.M., Heaven, S., Riley, K., 2011a. Energetic and environmental benefits of co-digestion of food waste and cattle slurry: A preliminary assessment. Resour. Conserv. Recy. 56, 71-79.

7. Banks, C.J., Chesshire, M., Heaven, S., Arnold, R., 2011b. Anaerobic digestion of source-segregated domestic food waste: Performance assessment by mass and energy balance. Bioresour. Technol. 102, 612-620.

8. Banks, C.J., Zhang, Y., 2010. Technical Report: Optimising inputs and outputs from anaerobic digestion processes. Defra Project Code WR0212. Department of the Environment, Food and Rural Affairs, London.

9. Banks, C.J., Chesshire, M., Stringfellow, A., 2008. A pilot-scale comparison of mesophilic and thermophilic digestion of source segregated domestic food waste. Water Sci. Technol. 58, 1475-1480.

10. Banks, C.J., Salter, A.M., Chesshire, M., 2007. Potential of anaerobic digestion for mitigation of greenhouse gas emissions and production of renewable energy from agriculture: barriers and incentives to widespread adoption in Europe. Water Sci. Technol. 55, 165-173.

11. BioAbV, 1998. Verordnung über die Verwertung von Bioabfällen auf landwirtschaftlich, forstwirtschaftlich und gärtnerisch genutzten Böden 
(Bioabfallverordnung - BioAbfV). Bundesministerium der Justiz, Germany. http://www.gesetze-im-internet.de/bioabfv/, accessed on 20th December 2011.

12. Braun, R., Wellinger, A., 2003. Potential of Co-digestion. IEA Task 37. http://www.iea-biogas.net/_download/publitask37/Potential\%20of\%20Codigestion\%20short\%20Brosch221203.pdf, accessed on 20th December 2011.

13. Callaghan, F.J., Wase, D.A.J., Thayanithy, K., Forster, C.F., 2002. Continuous codigestion of cattle slurry with fruit and vegetable wastes and chicken manure. Biomass Bioenerg. 22, 71-77.

14. Capela, I., Rodrigues, A., Silva, F., Nadais, H., Arroja, L., 2007. Impact of industrial sludge and cattle manure on anaerobic digestion of the OFMSW under mesophilic conditions. Biomass Bioenerg. 32, 245-251.

15. Clemens, J., Trimborn, M., Weiland, P., Amon, B., 2006. Mitigation of Greenhouse Gas Emissions from Livestock Production. Agr. Ecosyst. Environ. 112, 171-177.

16. El-Mashad, H.M., Zhang, R., 2010. Biogas production from co-digestion of dairy manure and food waste. Bioresour. Technol. 101, 4021-4028.

17. Hartmann, H., Ahring, B.K., 2005. Anaerobic digestion of the organic fraction of municipal solid waste: Influence of co-digestion with manure. Water Res. 39, 15431552 .

18. Holm-Nielsen, J.B., Al Seadi, T., Oleskowicz-Popiel, P., 2009. The future of anaerobic digestion and biogas utilization. Bioresour. Technol. 100 ,5478-5484.

19. Karakashev, D., Batstone, D.J., Trably, E., Angelidaki, I., 2006. Acetate oxidation is the dominant methanogenic pathway from acetate in the absence of Methanosaetaceae. Appl. Environ. Microbiol. 72, 5138-5141. 
20. Lukehurst, C.T., Frost, P., Al Seadi, T., 2010. Utilisation of digestate from biogas plants as biofertiliser. IEA Task 37. http://www.iea-biogas.net/_download/publitask37/Task37_Digestate_brochure9-2010.pdf, accessed on 20th December 2011.

21. Marañón, E., Salter, A.M., Castrillón, L., Heaven, S., Fernández-Nava, Y., 2011. Reducing the environmental impact of methane emissions from dairy farms by anaerobic digestion of cattle waste. Waste Manage. 31, 1745-1751.

22. Mata-Alvarez, J. (Ed.), 2003. Biomethanisation of the organic fraction of municipal solid wastes. IWA Publishing, London.

23. Neiva Correia, C., Vaz, F., Torres, A., 2008. Anaerobic Digestion of Biodegradable Waste - Operational and Stability Parameters for Stability Control. In: 5th IWA Int. Symp. on AD of Solid Wastes \& Energy Crops, Tunisia.

24. Nielsen, H.B., Angelidaki, I., 2008. Codigestion of manure and organic waste at centralized biogas plants:process imbalances and limitations. Water Sci. Technol. 58, $1521-1528$.

25. Palatsi, J., Viñas, M., Guivernau, M., Fernandez, B., Flotats, X., 2011. Anaerobic digestion of slaughterhouse waste: Main process limitations and microbial community interactions. Bioresour. Technol. 102, 2219-2227.

26. PAS 110, 2010. Specification for whole digestate, separated liquor and separated fibre derived from the anaerobic digestion of source-segregated biodegradable materials. British Standards Institution, London.

27. Raven, R.P.J.M., Gregersen, K.H., 2007. Biogas plants in Denmark: successes and setbacks. Renew. Sust. Energ. Rev. 11, 116-132. 
28. Resch, C., Worl, A., Waltenberger, R., Braun R., Kirchmayr, R., 2011.

Enhancement options for the utilisation of nitrogen rich animal by-products in anaerobic digestion. Bioresour. Technol. 102, 2503-2510.

29. Ripley, L.E., Boyle, W.C., Converse, J.C., 1986. Improved alkalimetric monitoring for anaerobic digestion of high-strength wastes. J. Water Pollut. Control Fed. 58, 406-411.

30. SCA, 1986. Methods for the determination of metals in soils, sediments and sewage sludge and plants by hydrochloric-nitric acid digestion. Methods for the Examination of Waters and Associated Materials, Standing Committee of Analysts, HMSO, London.

31. Schnurer, A., Nordberg, A., 2008. Ammonia, a selective agent for methane production by syntrophic acetate oxidation at mesophilic temperature. Water Sci. Technol. 57, 735-740.

32. Walker, M., Zhang, Y., Heaven, S., Banks, C.J., 2009. Potential errors in the quantitative evaluation of biogas production in anaerobic digestion processes. Bioresour. Technol. 100, 6339-6346.

33. Zhang, L., Lee, Y.-W., Jahng, D., 2011. Anaerobic co-digestion of food waste and piggery wastewater: Focusing on the role of trace elements. Bioresour. Technol. 102, 5048-5059. 


\section{Figure captions}

Fig. 1. Operational performance and stability characteristics of FW and CS co-digestion at 4-litre scale. Vertical dashed lines indicate when a change of OLR or VS ratio of FW to CS took place.

Fig. 2. Operational performance and stability characteristics of FW and $\mathrm{CP}$ co-digestion at 4-litre scale. Vertical dashed lines indicate when a change of OLR or feeding regime took place.

Fig. 3. Operational performance and stability characteristics of FW and co-substrates digestion at 75-litre scale.

Fig. 4. Simulated essential elements concentration-time profile in the 75-litre food waste only digester (day 0 and 140 was when a sample of digestate was taken for trace element analysis and day 210 was when VFA level rose to above $1000 \mathrm{mg}^{-1}$.)

Fig. 5. Residual methane potential test on digestate from the 75-litre digestion trial. 


\section{Table 1}

Substrate characteristics.

\begin{tabular}{|c|c|c|c|}
\hline & Food waste & Cattle slurry & Card packaging $^{\mathrm{d}}$ \\
\hline \multicolumn{4}{|l|}{ General } \\
\hline $\mathrm{pH}(1: 5$ dilution for $\mathrm{FW}$ and $\mathrm{CS}, 1: 30$ for $\mathrm{CP})$ & $4.71 \pm 0.01$ & $7.83 \pm 0.07$ & $7.21 \pm 0.03$ \\
\hline TS (\% wet weight (WW)) & $23.74 \pm 0.08$ & $9.31 \pm 0.14$ & $93.9 \pm 0.1$ \\
\hline $\mathrm{VS}(\% \mathrm{WW})$ & $21.71 \pm 0.09$ & $6.52 \pm 0.04$ & $78.5 \pm 0.4$ \\
\hline VS (\% of TS) & $91.44 \pm 0.39$ & $70.0 \pm 0.6$ & $83.6 \pm 0.5$ \\
\hline Total Organic Carbon (TOC) (\% of TS) & $47.6 \pm 0.5$ & $38.9 \pm 1.0$ & $41.6 \pm 0.7$ \\
\hline TOC / TKN & $13.9 \pm 0.2$ & $11.1 \pm 0.3$ & $288 \pm 5$ \\
\hline Biodegradable $\mathrm{C}^{\text {a }}$ / TKN & $13.6 \pm 0.2$ & $8.15 \pm 0.32$ & $42.9 \pm 4.7$ \\
\hline Calorific value (CV) $\left(\mathrm{kJ} \mathrm{g}^{-1} \mathrm{TS}\right)$ & $20.7 \pm 0.2$ & $16.75 \pm 0.10$ & $17.18 \pm 0.36$ \\
\hline \multicolumn{4}{|l|}{ Biochemical composition (VS basis) } \\
\hline Carbohydrates $^{\mathrm{b}}\left(\mathrm{g} \mathrm{kg}^{-1}\right)$ & $453 \pm 17$ & $21.9 \pm 1.0$ & $242 \pm 19$ \\
\hline $\operatorname{Lipids}^{\mathrm{c}}\left(\mathrm{g} \mathrm{kg}^{-1}\right)$ & $151 \pm 1$ & $93.6 \pm 0.8$ & $<10$ \\
\hline Crude proteins $\left(\mathrm{g} \mathrm{kg}^{-1}\right)$ & $235 \pm 3$ & $276 \pm 6$ & $10.8 \pm 0.0$ \\
\hline Hemi-cellulose $\left(\mathrm{g} \mathrm{kg}^{-1}\right)$ & $38.1 \pm 3.7$ & $226 \pm 6$ & $113 \pm 5$ \\
\hline Cellulose $\left(\mathrm{g} \mathrm{kg}^{-1}\right)$ & $50.4 \pm 1.6$ & $96.7 \pm 8.5$ & $304 \pm 6$ \\
\hline $\operatorname{Lignin}\left(\mathrm{g} \mathrm{kg}^{-1}\right)$ & $16.5 \pm 0.2$ & $226 \pm 7$ & $532 \pm 2$ \\
\hline \multicolumn{4}{|l|}{ NPK and PTE content (TS basis) } \\
\hline Total Kjeldahl nitrogen $(\mathrm{TKN})\left(\mathrm{g} \mathrm{kg}^{-1}\right)$ & $34.2 \pm 0.4$ & $35.0 \pm 0.5$ & $1.44 \pm 0.01$ \\
\hline Total Phosphorus (TP) $\left(\mathrm{g} \mathrm{kg}^{-1}\right)$ & $5.41 \pm 0.32$ & $8.58 \pm 0.63$ & $0.134 \pm 0.003$ \\
\hline Total Potassium (TK) $\left(\mathrm{g} \mathrm{kg}^{-1}\right)$ & $14.3 \pm 0.8$ & $16.7 \pm 0.2$ & $0.221 \pm 0.010$ \\
\hline $\mathrm{Cd}\left(\mathrm{mg} \mathrm{kg}^{-1}\right)$ & $<1.0$ & $<1.0$ & $<0.05$ \\
\hline $\mathrm{Cr}\left(\mathrm{mg} \mathrm{kg}^{-1}\right)$ & $29.0 \pm 1.2$ & $113 \pm 2$ & $9.1 \pm 0.9$ \\
\hline $\mathrm{Cu}\left(\mathrm{mg} \mathrm{kg}^{-1}\right)$ & $7.20 \pm 0.81$ & $58.4 \pm 1.1$ & $20.3 \pm 2.3$ \\
\hline $\mathrm{Hg}\left(\mathrm{mg} \mathrm{kg}^{-1}\right)$ & $<0.010$ & $<0.010$ & $<0.10$ \\
\hline $\mathrm{Ni}\left(\mathrm{mg} \mathrm{kg}^{-1}\right)$ & $7.0 \pm 2.9$ & $44.8 \pm 0.6$ & $4.5 \pm 0.5$ \\
\hline $\mathrm{Pb}\left(\mathrm{mg} \mathrm{kg}^{-1}\right)$ & $<10$ & $<10$ & $2.9 \pm 0.4$ \\
\hline $\mathrm{Zn}\left(\mathrm{mg} \mathrm{kg}^{-1}\right)$ & $33 \pm 11$ & $231 \pm 6$ & $16.2 \pm 4.3$ \\
\hline \multicolumn{4}{|l|}{ Elemental composition (TS basis) } \\
\hline $\mathrm{N}(\%)$ & $3.44 \pm 0.04$ & $3.50 \pm 0.05$ & $0.14 \pm 0.00$ \\
\hline $\mathrm{C}(\%)$ & $47.6 \pm 0.5$ & $38.9 \pm 1.0$ & $41.6 \pm 0.7$ \\
\hline $\mathrm{H}(\%)$ & $7.04 \pm 0.63$ & $5.18 \pm 0.15$ & $4.76 \pm 0.23$ \\
\hline $\mathrm{S}(\%)$ & $0.15 \pm 0.01$ & $0.31 \pm 0.02$ & $0.21 \pm 0.00$ \\
\hline $\mathrm{O}(\%)$ & $33.3 \pm 2.6$ & $23.1 \pm 0.9$ & $36.9 \pm 0.9$ \\
\hline
\end{tabular}

${ }^{a}$ Biodegradable carbon was calculated by deducting lignin carbon from TOC. The formula of lignin was chosen as $\mathrm{C}_{9} \mathrm{H}_{7.95} \mathrm{O}_{2.41}(\mathrm{OMe})_{0.93}$;

${ }^{\mathrm{b}}$ In equivalent glucose;

${ }^{c} \mathrm{n}$-hexane extractable material (HEM);

${ }^{\mathrm{d}}$ Card packaging used for characteristics determination was the dry material as used in the 75-litre trial. 


\section{Table 2}

Operational regimes for the 4-litre laboratory-scale digestion trials.

\begin{tabular}{|c|c|c|c|c|c|}
\hline Time (days) & $\mathrm{FW}+\mathrm{CS} 1$ & $\mathrm{FW}+\mathrm{CS} 2$ & $\mathrm{FW}+\mathrm{CP} 1$ & $\mathrm{FW}+\mathrm{CP} 2$ & $\mathrm{FW}$ \\
\hline 35 & \multirow[b]{2}{*}{$\begin{array}{c}\mathrm{OLR}=2, \\
\mathrm{FW}: \mathrm{CS}= \\
20: 80^{\mathrm{a}}\end{array}$} & \multirow[b]{2}{*}{$\begin{array}{c}\text { OLR }=2, \\
\text { FW:CS = } \\
20: 80\end{array}$} & \multirow[b]{2}{*}{$\mathrm{OLR}=2^{\mathrm{b}}$} & \multirow[b]{2}{*}{ OLR $=2$} & OLR $=2$ \\
\hline 98 & & & & & \multirow{6}{*}{$\begin{array}{c}\text { Ceased } \\
\text { feeding from } \\
\text { day } 35 \\
\text { onwards }\end{array}$} \\
\hline 133 & \multirow{2}{*}{$\begin{array}{c}\text { OLR }=2, \\
\text { FW:CS = } \\
40: 60\end{array}$} & \multirow{2}{*}{$\begin{array}{c}\text { OLR }=2, \\
\text { FW:CS = } \\
40: 60\end{array}$} & $\mathrm{OLR}=3$ & OLR $=3$ & \\
\hline 175 & & & $\begin{array}{l}\text { Fed with cattle } \\
\text { slurry }\end{array}$ & $\begin{array}{l}\text { Ceased } \\
\text { feeding }\end{array}$ & \\
\hline 231 & $\begin{array}{c}\text { OLR }=3, \\
\text { FW:CS = } \\
40: 60\end{array}$ & $\begin{array}{c}\text { OLR }=3, \\
\text { FW:CS = } \\
40: 60\end{array}$ & $\mathrm{OLR}=2$ & $\mathrm{OLR}=2^{\mathrm{c}}$ & \\
\hline 294 & $\begin{array}{c}\text { OLR }=3, \\
\text { FW:CS = } \\
60: 40\end{array}$ & $\begin{array}{c}\text { OLR }=3, \\
\text { FW:CS = } \\
60: 40\end{array}$ & $\mathrm{OLR}=3$ & $\mathrm{OLR}=3$ & \\
\hline 329 & $\begin{array}{c}\text { OLR }=4, \\
\text { FW:CS = } \\
60: 40\end{array}$ & $\begin{array}{c}\mathrm{OLR}=4, \\
\text { FW:CS = } \\
60: 40\end{array}$ & $\mathrm{OLR}=4$ & $\mathrm{OLR}=4$ & \\
\hline $\begin{array}{l}\text { Tote: FW - Fo } \\
\text { The proportio }\end{array}$ & $\begin{array}{l}\text { te; CS - } \\
\text { d waste } \\
\text { d waste }\end{array}$ & $\begin{array}{l}\text { lurry; CP } \\
\text { le slurry w } \\
\text { l packagin }\end{array}$ & $\begin{array}{l}\text { rd packaging } \\
\text { a VS basis; } \\
53: 47 \text { on a }\end{array}$ & s throug & 4-litre \\
\hline
\end{tabular}




\section{Table 3}

Nutrient (NPK), PTE and solids content of the wastewater biosolids digestate used as the inoculum for the 75-litre trial.

\begin{tabular}{|c|c|c|c|}
\hline & Whole digestate & Liquor fraction & Fibre fraction \\
\hline TAN $\left(\mathrm{g} \mathrm{NH}_{3}-\mathrm{N} \mathrm{kg}^{-1} \mathrm{TS}\right)$ & $39.1 \pm 0.5$ & $40.1 \pm 0.3$ & \\
\hline TKN $\left(\mathrm{g} \mathrm{N} \mathrm{kg}^{-1} \mathrm{TS}\right)$ & $77.5 \pm 1.5$ & $79.3 \pm 1.1$ & $43.4 \pm 1.0$ \\
\hline $\mathrm{TK}\left(\mathrm{g} \mathrm{K} \mathrm{kg}^{-1} \mathrm{TS}\right)$ & $2.90 \pm 0.29$ & $2.99 \pm 0.13$ & $1.26 \pm 0.26$ \\
\hline $\mathrm{TP}\left(\mathrm{g} \mathrm{P} \mathrm{kg}^{-1} \mathrm{TS}\right)$ & $32.4 \pm 3.5$ & $33.2 \pm 1.3$ & $16.8 \pm 2.6$ \\
\hline $\mathrm{Cd}\left(\mathrm{mg} \mathrm{kg}^{-1} \mathrm{TS}\right)$ & $1.10 \pm 0.21$ & $1.10 \pm 0.10$ & $<1.0$ \\
\hline $\mathrm{Cr}\left(\mathrm{mg} \mathrm{kg}^{-1} \mathrm{TS}\right)$ & $67.3 \pm 5.3$ & $68.8 \pm 5.3$ & $40.1 \pm 2.2$ \\
\hline $\mathrm{Cu}\left(\mathrm{mg} \mathrm{kg}^{-1} \mathrm{TS}\right)$ & $462 \pm 9$ & $473 \pm 1$ & $247 \pm 24$ \\
\hline $\mathrm{Ni}\left(\mathrm{mg} \mathrm{kg}^{-1} \mathrm{TS}\right)$ & $52.9 \pm 7.4$ & $54.0 \pm 7.5$ & $32.5 \pm 2.1$ \\
\hline $\mathrm{Pb}\left(\mathrm{mg} \mathrm{kg}^{-1} \mathrm{TS}\right)$ & $83.8 \pm 8.4$ & $83.9 \pm 0.7$ & $61.9 \pm 8.0$ \\
\hline $\mathrm{Zn}\left(\mathrm{mg} \mathrm{kg}^{-1} \mathrm{TS}\right)$ & $718 \pm 27$ & $736 \pm 24$ & $380 \pm 24$ \\
\hline TS (\% WW) & $4.48 \pm 0.07$ & $4.10 \pm 0.01$ & $10.8 \pm 0.6$ \\
\hline VS (\% WW) & $2.81 \pm 0.02$ & $2.54 \pm 0.01$ & $8.56 \pm 0.58$ \\
\hline VS (\% TS) & $62.8 \pm 1.4$ & $62.0 \pm 0.1$ & $79.8 \pm 0.5$ \\
\hline
\end{tabular}




\section{Table 4}

Concentrations of essential elements $\left(\mathrm{mg} \mathrm{kg}^{-1} \mathrm{TS}\right)$ in whole digestate samples from 4litre and 75-litre co-digestion trials.

\begin{tabular}{|c|c|c|c|c|c|c|c|c|}
\hline Digester & Co & $\mathbf{C u}$ & Mn & Mo & $\mathbf{N i}$ & Se & $\mathbf{W}$ & $\mathbf{Z n}$ \\
\hline \multicolumn{9}{|c|}{ 4-litre food waste co-digestion trials (day 161) ${ }^{a}$} \\
\hline FW + CS, No. 1 & 2.0 & 63.2 & 667 & 6.9 & 62.4 & 0.46 & 3.1 & 241 \\
\hline FW + CP, No. 1 & 1.2 & 75.7 & 443 & 3.3 & 28.4 & 0.26 & $<0.25$ & 173 \\
\hline FW + CP, No. 2 & 1.2 & 73.9 & 171 & 5.9 & 53.5 & 0.16 & 3.3 & 96.8 \\
\hline FW control & 1.3 & 140 & 255 & 7.9 & 132 & 0.33 & 6.1 & 121 \\
\hline \multicolumn{9}{|c|}{ 75-litre food waste co-digestion trials (day 140) } \\
\hline $\mathbf{F W}+\mathbf{C S}$ & 1.8 & 196 & 696 & 3.9 & 36.3 & 0.59 & $<0.25$ & 314 \\
\hline $\mathbf{F W}+\mathbf{C P}$ & 1.3 & 178 & 163 & 3.3 & 36.5 & $<0.15$ & 2.1 & 198 \\
\hline FW control & 1.5 & 209 & 367 & 3.1 & 65.0 & 0.57 & 1.6 & 287 \\
\hline
\end{tabular}

${ }^{a}$ Samples for trace element analysis were taken from FW + CS digester No. 1, and from both FW + CP digesters to take account of the different treatments (FP + CP No. 1 fed with CS from Day $134-176$, FW + CP No. 2 not fed for the same period). 
Table 5

Characteristics of whole digestate, digestate liquor and digestate fibre in 75-litre trials.

\begin{tabular}{|c|c|c|c|c|c|c|c|c|c|c|c|}
\hline & \multicolumn{3}{|c|}{ Whole digestate } & \multicolumn{3}{|c|}{ Digestate liquor } & \multicolumn{3}{|c|}{ Digestate fibre } & \multirow{2}{*}{$\begin{array}{l}\text { Bio } \\
\text { AbV }\end{array}$} & \multirow{2}{*}{$\begin{array}{l}\text { PAS } \\
110\end{array}$} \\
\hline & $\begin{array}{l}\text { FW + } \\
\text { CS }\end{array}$ & $\begin{array}{l}\text { FW + } \\
\text { CP }\end{array}$ & $\begin{array}{l}\text { FW } \\
\text { only }\end{array}$ & $\begin{array}{l}\text { FW + } \\
\text { CS }\end{array}$ & $\begin{array}{l}\mathbf{F W}+ \\
\mathbf{C P}\end{array}$ & $\begin{array}{l}\text { FW } \\
\text { only }\end{array}$ & $\begin{array}{l}\text { FW + } \\
\text { CS }\end{array}$ & $\begin{array}{l}\mathbf{F W}+ \\
\mathbf{C P}\end{array}$ & $\begin{array}{l}\text { FW } \\
\text { only }\end{array}$ & & \\
\hline \multicolumn{12}{|c|}{ Nutrients $\left(\mathrm{g} \mathrm{kg}^{-1} \mathrm{TS}\right)$} \\
\hline TKN & 58.8 & 65.3 & 136 & 65.2 & 70.6 & 138 & 32.2 & 33 & 62.2 & & \\
\hline TP & 13 & 8.9 & 14 & 14 & 10 & 14 & 5.6 & 3.1 & 13 & & \\
\hline TK & 34 & 25 & 50 & 38 & 29 & 50 & 11 & 9.5 & 24 & & \\
\hline \multicolumn{12}{|c|}{ Potentially toxic elements $\left(\mathrm{mg} \mathrm{kg}^{-1} \mathrm{TS}\right)$} \\
\hline $\mathrm{Cd}$ & $<0.50$ & $<0.50$ & $<0.50$ & $<1.0$ & $<1.0$ & $<1.0$ & $<0.50$ & $<0.50$ & $<0.50$ & 1.0 & 1.5 \\
\hline $\mathrm{Cr}$ & 31 & 53 & 79 & 23 & 60 & 79 & 68 & 24 & 51 & 70 & 100 \\
\hline $\mathrm{Cu}$ & 100 & 160 & 130 & 110 & 180 & 130 & 46 & 61 & 71 & 70 & 200 \\
\hline $\mathrm{Pb}$ & $<10$ & 52 & 18 & $<18$ & 62 & 18 & $<10$ & 14 & $<10$ & 100 & 200 \\
\hline $\mathrm{Hg}$ & $<0.25$ & $<0.25$ & $<0.25$ & $<0.50$ & $<0.50$ & $<0.50$ & $<0.25$ & $<0.25$ & $<0.25$ & 0.7 & 1 \\
\hline $\mathrm{Ni}$ & 16 & 29 & 48 & 13 & 33 & 49 & 32 & 13 & 28 & 35 & 50 \\
\hline $\mathrm{Zn}$ & 270 & 130 & 180 & 300 & 150 & 180 & 140 & 50 & 130 & 300 & 400 \\
\hline \multicolumn{12}{|c|}{ Essential elements $\left(\mathrm{mg} \mathrm{kg}^{-1} \mathrm{TS}\right)$} \\
\hline Co & $<1.0$ & $<1.0$ & $<1.0$ & $<2.0$ & $<2.0$ & $<2.0$ & 1.3 & $<1.0$ & $<1.0$ & & \\
\hline $\mathrm{Fe}$ & $<2000$ & 3200 & 5700 & $<4000$ & 4100 & 5700 & $<2000$ & $<2000$ & 2700 & & \\
\hline Mo & 3.9 & 5.4 & 5.2 & 4.2 & 6.2 & 5.2 & 2.3 & 2.3 & 2.7 & & \\
\hline $\mathrm{Se}$ & $<0.30$ & $<0.30$ & 0.7 & $<0.50$ & $<0.50$ & 0.71 & $<0.30$ & $<0.30$ & $<0.30$ & & \\
\hline $\mathrm{W}$ & $<1.0$ & $<1.0$ & $<1.0$ & $<2.0$ & $<2.0$ & $<2.0$ & $<1.0$ & $<1.0$ & $<1.0$ & & \\
\hline \multicolumn{12}{|c|}{ Solids content $(\% \mathrm{WW})$} \\
\hline TS & 5.84 & 6.76 & 6.04 & 4.72 & 5.16 & 5.95 & 11.4 & 12.7 & 14.1 & & \\
\hline VS & 4.38 & 4.45 & 4.19 & 3.34 & 3.21 & 4.1 & 9.7 & 9.33 & 11.2 & & \\
\hline
\end{tabular}


Fig. 1.

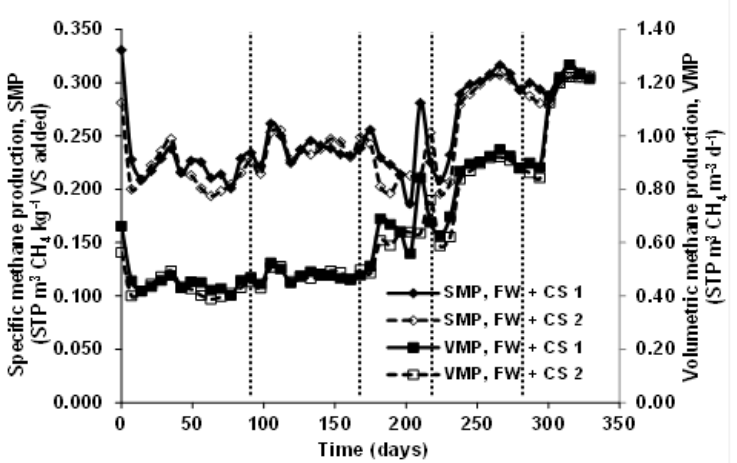

a. Weekly average specific methane production

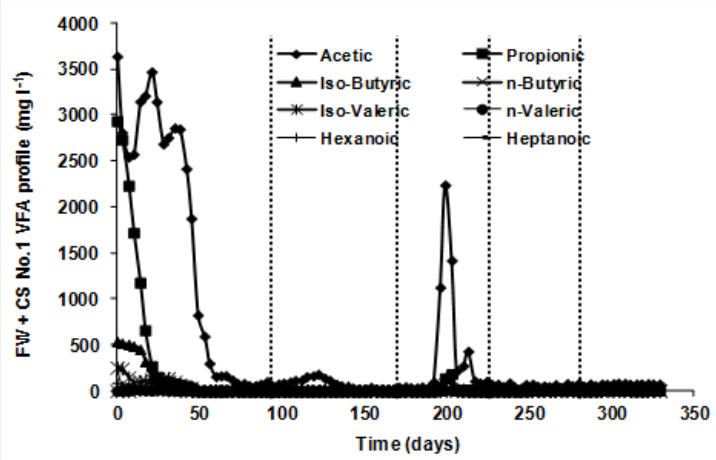

c. VFA concentration profile (Digester No. 1)

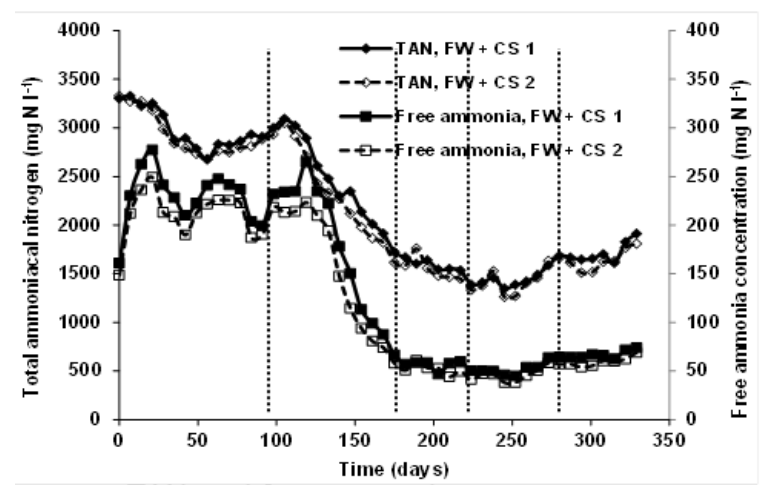

e. TAN and free ammonia

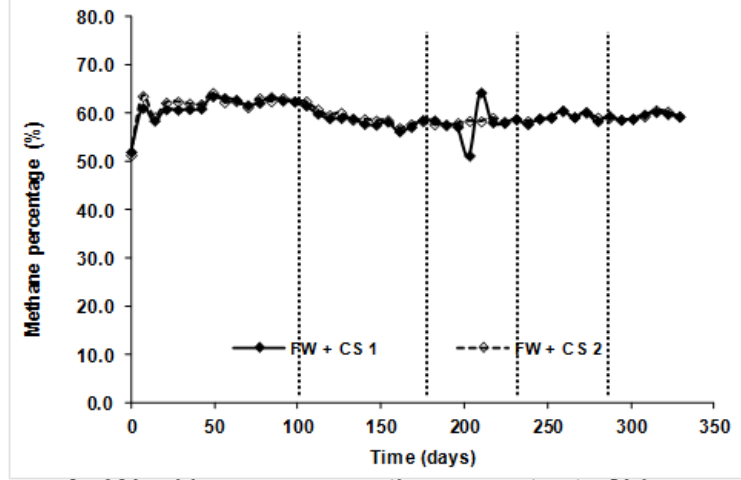

b. Weekly average methane content of biogas

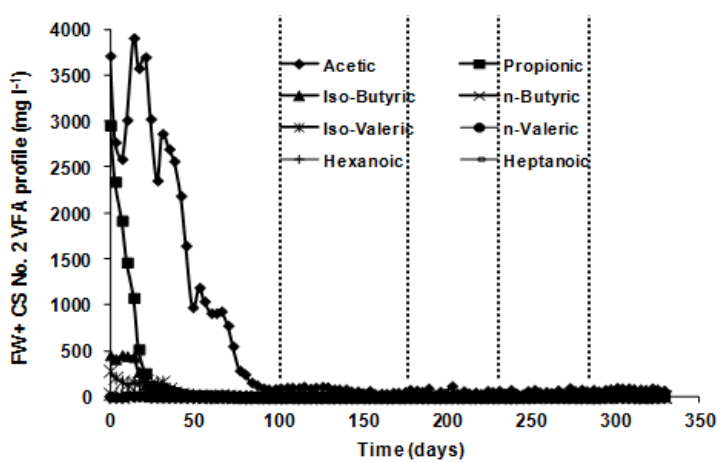

d. VFA concentration profile (Digester No. 2)

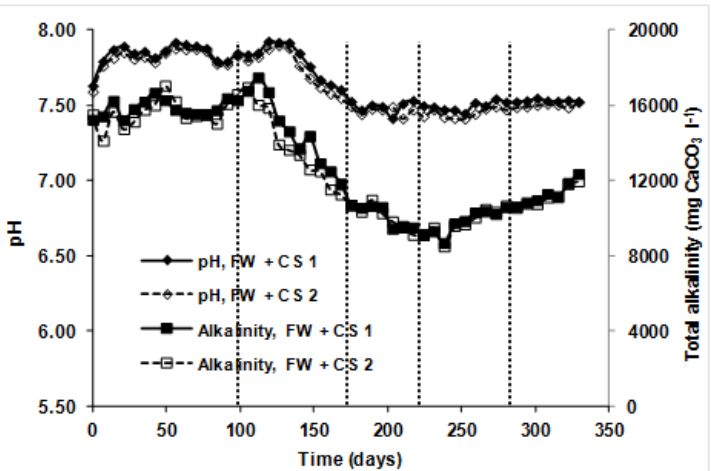

f. $\mathrm{pH}$ and alkalinity 
Fig. 2.

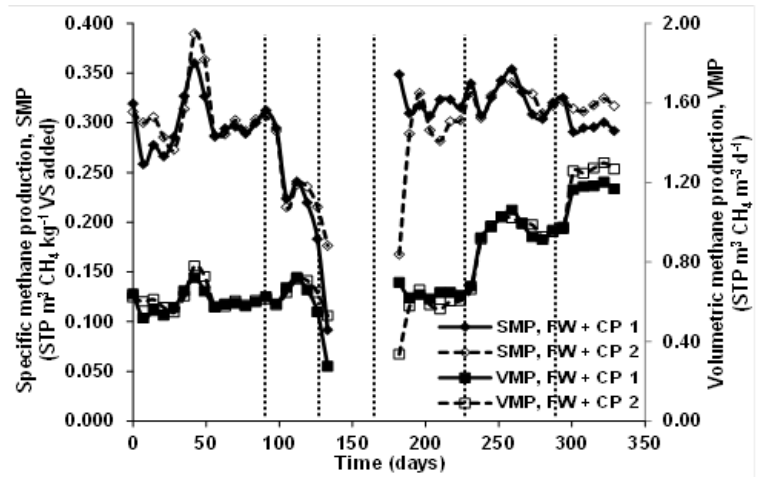

a. Weekly average specific methane production

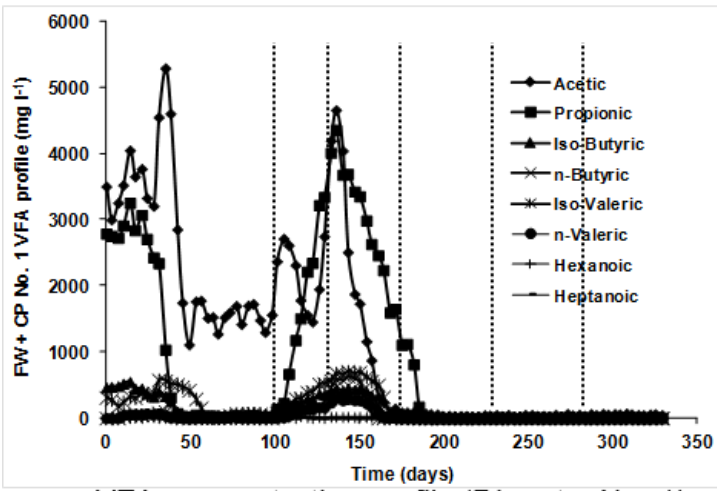

c. VFA concentration profile (Digester No. 1)

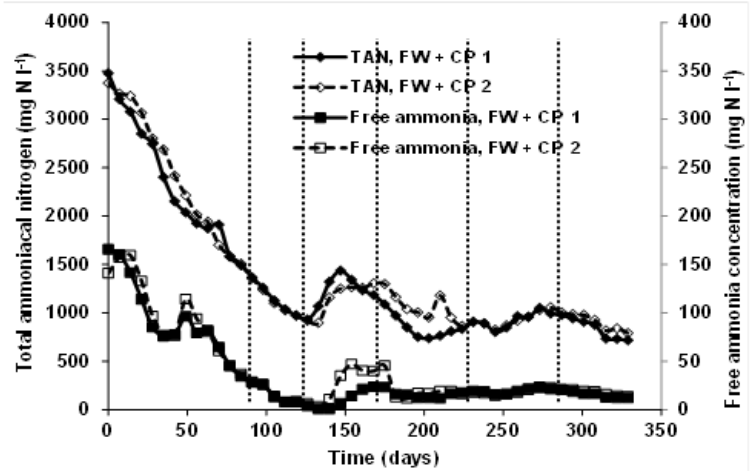

e. TAN and free ammonia

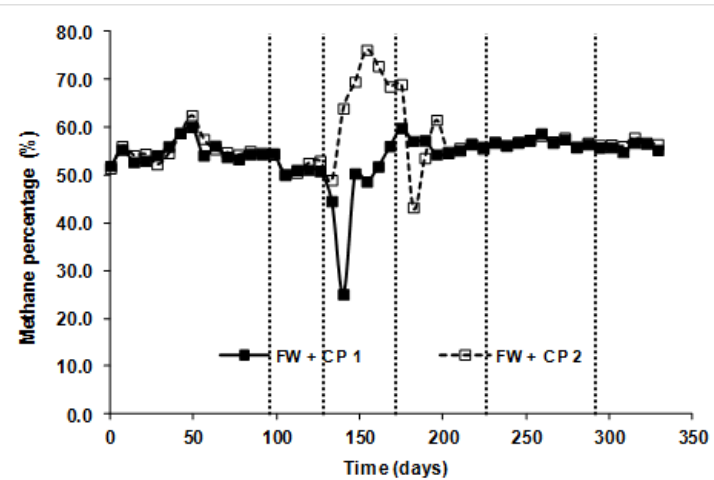

b. Weekly average methane content of biogas

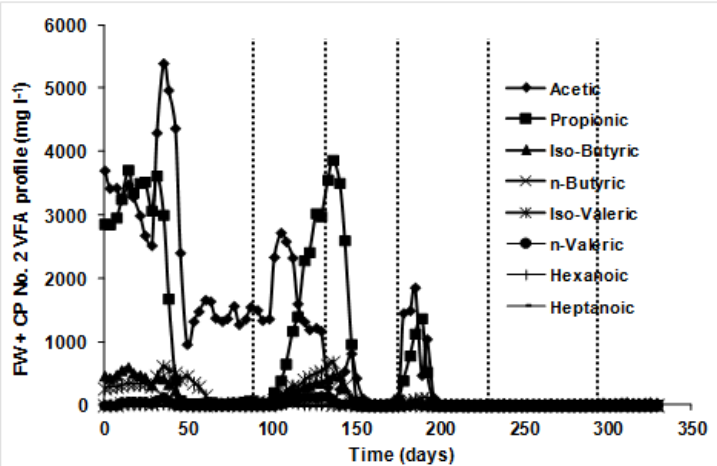

d. VFA concentration profile (Digester No. 2)

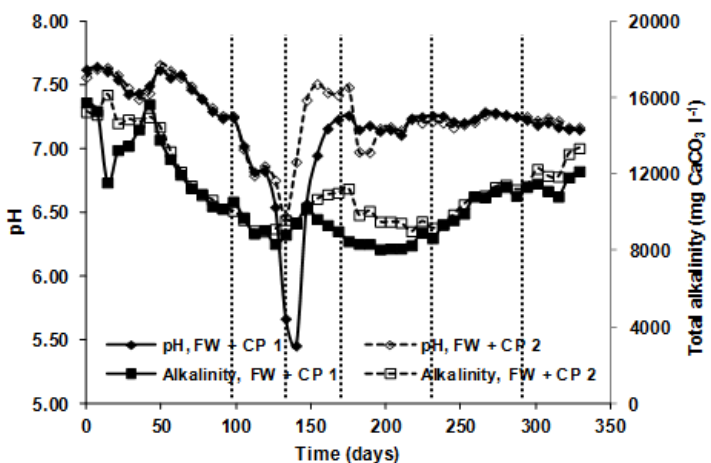

f. $\mathrm{pH}$ and alkalinity 
Fig. 3.

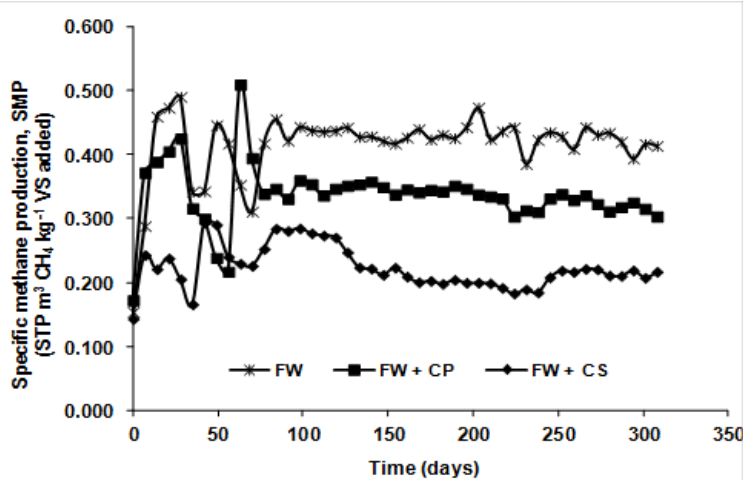

a. Weekly average specific methane production

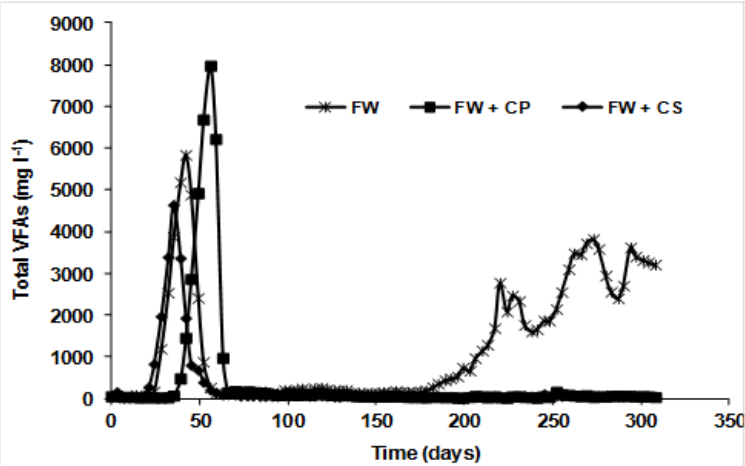

c. Total VFA concentration

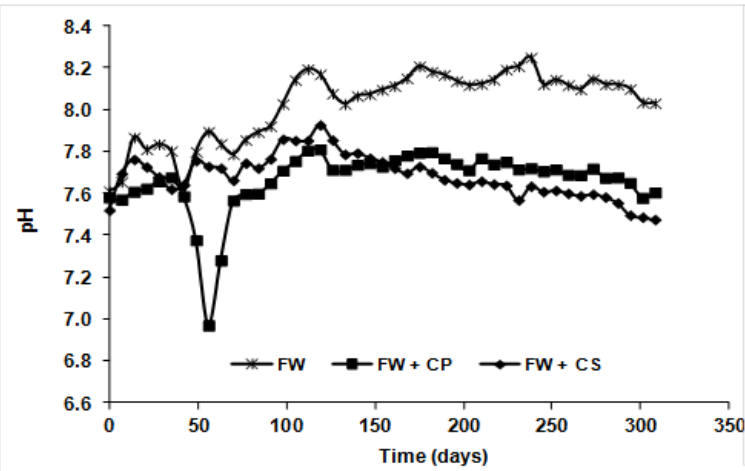

e. $\mathrm{pH}$

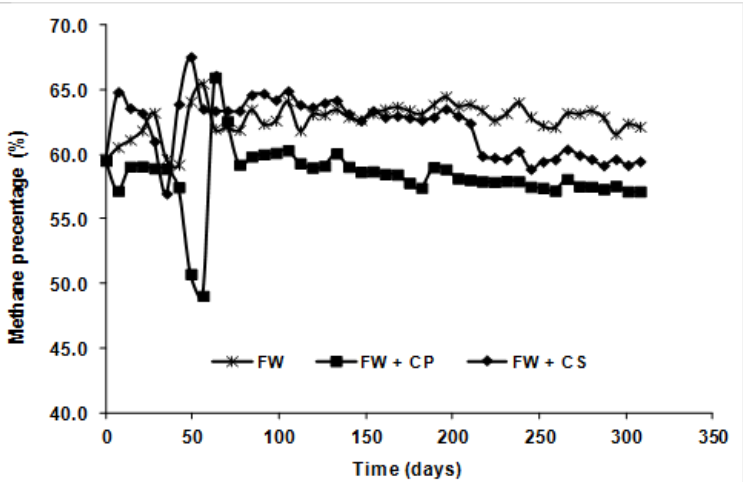

b. Weekly average methane content of biogas

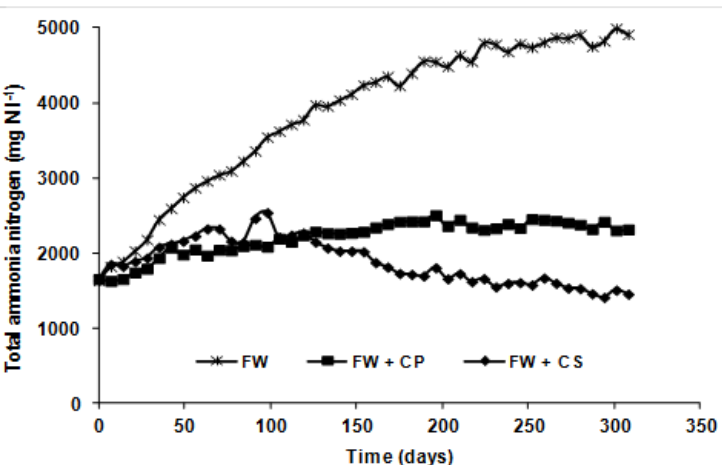

d. Total ammoniacal nitrogen

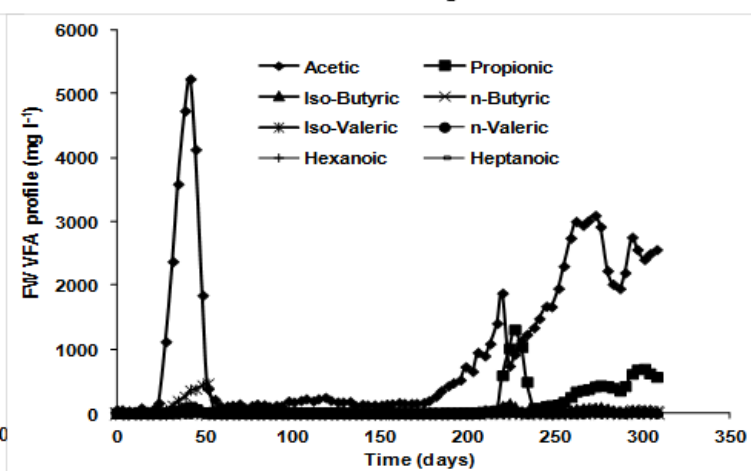

f. VFA concentration profile in FW-only digester 
Fig. 4.

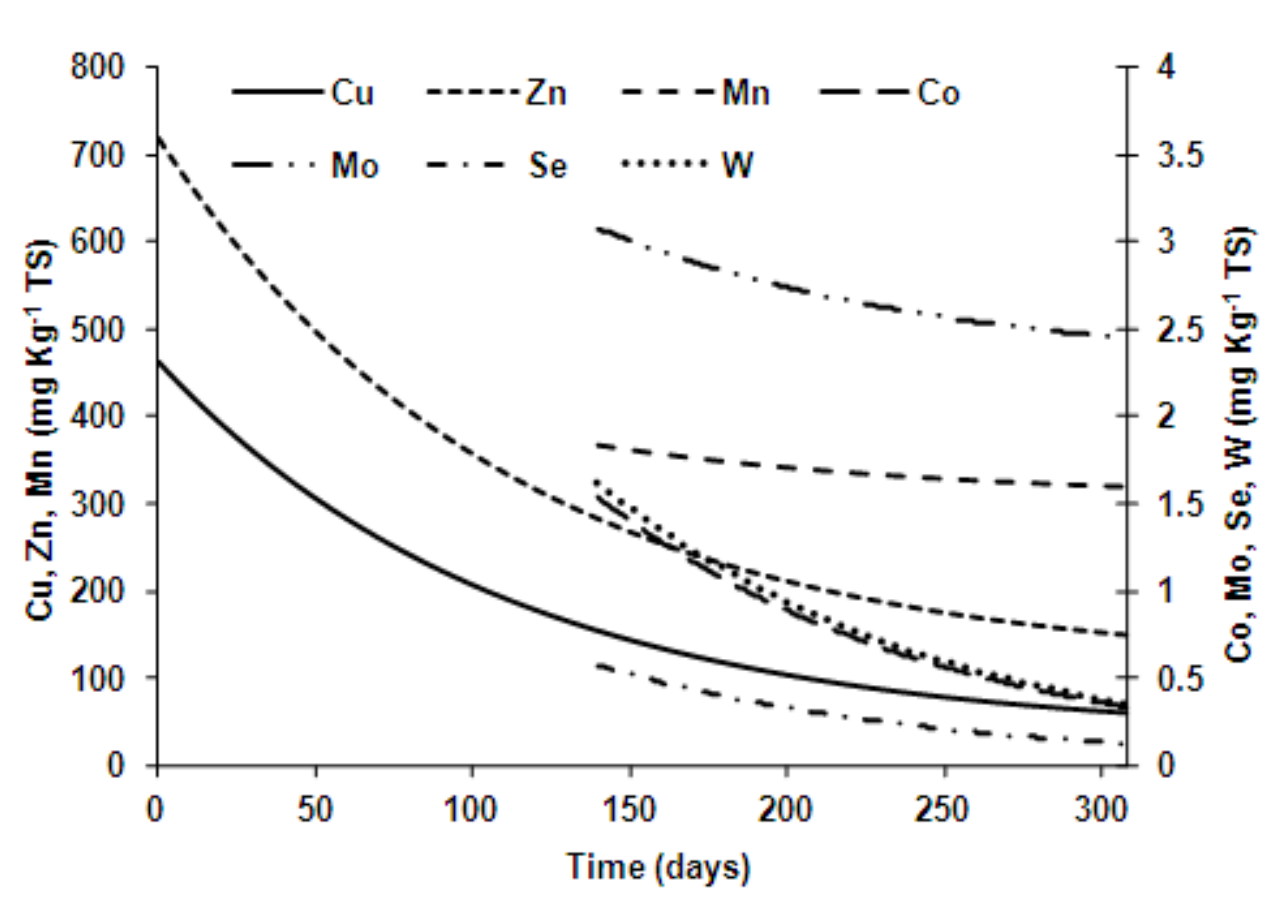


Fig. 5.
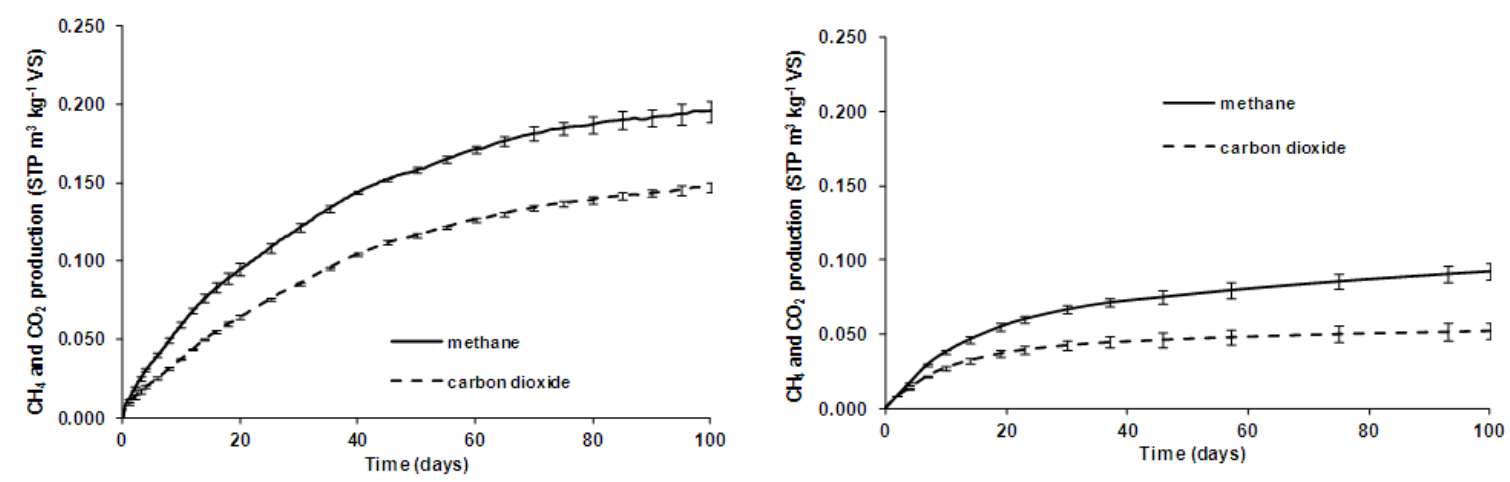

a. $F W+C S$ digestate fibre

b. $F W+C S$ digestate liquor

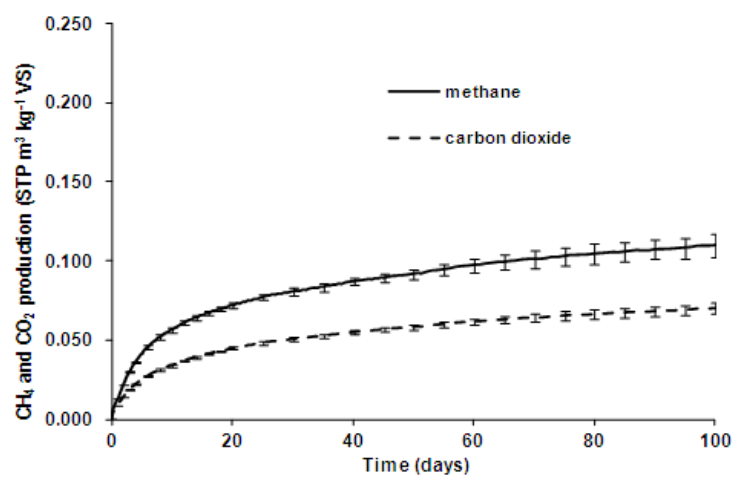

c. $F W+C P$ digestate fibre

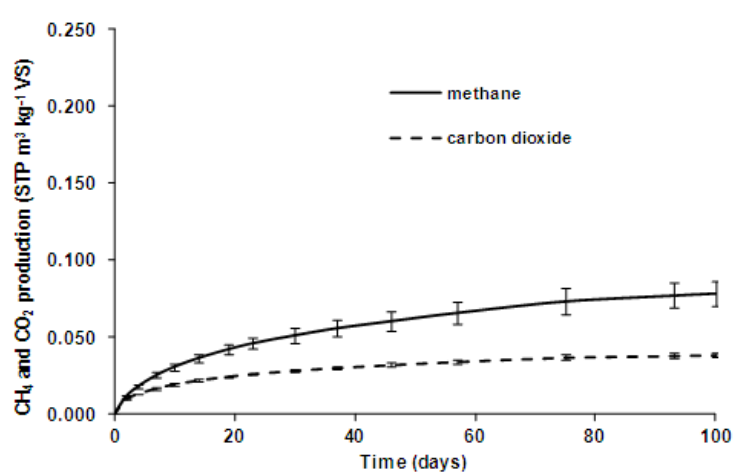

d. FW + CP digestate liquor

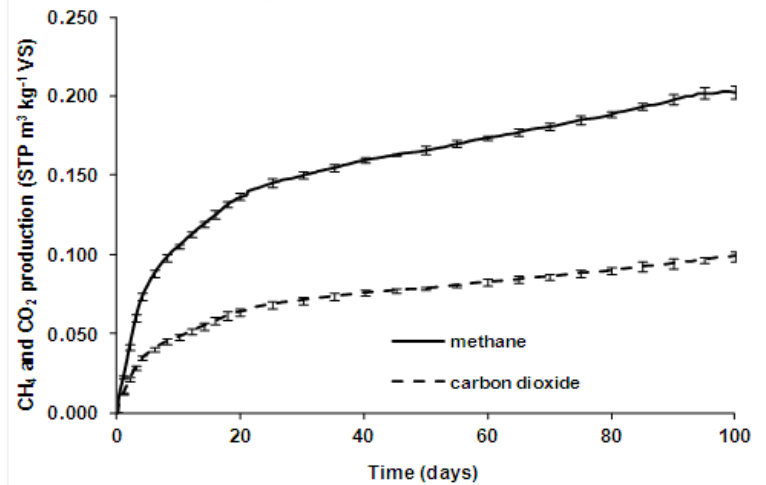

e. FW-only whole digestate 